\title{
竜洋海岸の離岸堤周辺で近年起こりつつある海浜変形モードの変化
}

\section{Mode Shift of Beach Changes Recently Occurring around Detached Breakwaters on Ryuyo Coast}

\author{
宇多高明 ${ }^{1} \cdot$ 三波俊郎 $^{2} \cdot$ 石川仁憲 $^{3} \cdot$ 白石慎重 $^{4} \cdot$ 佐藤純一郎 $^{5}$
}

Takaaki UDA, Toshiro SAN-NAMI, Toshinori ISHIKAWA, Norifusa SHIRAISHI and Jun-ichiro SATO

\begin{abstract}
The beach topography around the detached breakwaters of the Ryuyo coast located immediately east of the Tenryu River mouth was observed to investigate the beach changes. On the basis of the aerial photographs and bathymetric survey data taken since 2007, beach changes in the area between the detached breakwaters and the river mouth were analyzed. $5 \mathrm{~m}^{3}$ of color sand was placed at the shoreline and subsequent dispersion of the color sand along the shoreline was measured. The detached breakwaters were found to be the solid boundary at present, although eastward longshore sand transport existed in the past, because of decrease in sand supply from the river mouth.
\end{abstract}

\section{1.はじめに}

天竜川河口左岸に位置する竜洋海岸では，天竜川から の流下土砂が東向きの沿岸漂砂によって運ばれる条件下 にあったが，1980年代以降天竜川からの供給土砂量の減 少に伴って汀線が後退し，1992年には80m，1994年には $125 \mathrm{~m}$ にわたって護岸が壊れた。このため，対策として 1995年までに5 基の離岸堤が造られた（図-1参照）。これ らの離岸堤は東向きの沿岸漂砂を阻止したために, 離岸 堤の東側直近の汀線後退を招いた。この地区には保安林 の堤防があるため, 浜幅が狭くなった場所では堤防の表 のり面が露出し，被災の危険が高まった。このことから， 離岸堤群により阻止された東向き沿岸漂砂を離岸堤の天 端高を下げることにより下手側へ流す方策について検討 が進められた（宇多ら，2008）。しかし実際には，天竜 川からの土砂供給量が激減している現在, 竜洋海岸の離 岸堤付近で現在もなお東向きの沿岸漂砂が卓越している かどうかは不明であった。このことから，本研究では 2007 年以降の空中写真, 深浅測量デー夕を基に離岸堤周 辺での地形変化を分析するとともに，離岸堤群の両端付 近でカラーサンド (中砂 $\left.5 \mathrm{~m}^{3}\right)$ を投入し, 汀線に沿うト レーサーの広がりを調べて漂砂特性を把握した。

\section{2. 竜洋海岸の波浪条件と天竜川の流量}

図-2には竜洋海岸沖で行われている波浪観測データよ り2007年 1 月から 2011 年 1 月までの観測結果 $\left(H_{1 / 3}, T_{1 / 3}\right)$ を示す。同時に，同じ期間における天竜川での洪水の発

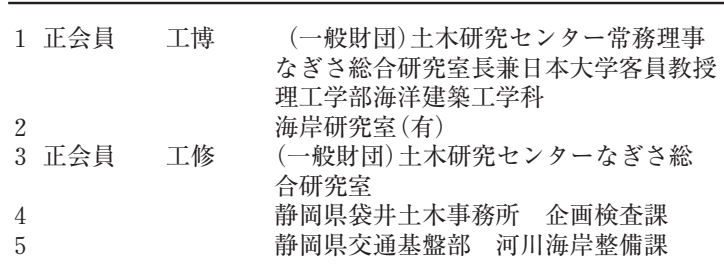

生状況について, 河口の上流 $3.3 \mathrm{~km}$ に位置する掛塚観測 所における流量の経時変化も示す。この間, 規模の大き な洪水は 2 回（2007年7月 15 日 13 時の $5,532 \mathrm{~m}^{3}$ と 2010 年 7 月 15 日 2 時の $3,642 \mathrm{~m}^{3}$ ) 発生している。このうち 2007 年 7 月 15 日の水位は観測史上既往最高水位を記録し, 洪水流 量は $8,055 \mathrm{~m}^{3} / \mathrm{s}$ （鹿島観測所：河口から $25 \mathrm{~km}$ 地点）と天 竜川の計画高水流量 $14,000 \mathrm{~m}^{3} / \mathrm{s}$ の 6 割の規模であった. これら以外では規模の大きな洪水は発生していない.

\section{3. 空中写真判読による海浜地形変化の把握}

調査対象区域は，天竜川河口左岸から福田漁港まで続 く9.5km の海岸線のうち, 図-1に矩形で示す沿岸方向に $5.7 \mathrm{~km}$ の区域である。この矩形区域における2007年以降 の拡大空中写真を図-3に示す。対象区域の中央には離岸 堤群がある。また，離岸堤群の東 $1.2 \mathrm{~km}$ には 6 号離岸堤 が2009年以降建設中である (図-3の矢印).なお, 離岸 堤については天竜川河口側から 1,2 号と呼んで区別する. 2007年では，天竜川河口には右岸側から細長い河口砂州 が伸びており, 開口部はほぼ左岸付近にあった。以後, 2011 年に至るまで右岸河口砂州は恒常的に右岸側から細 長く伸びている．また，左岸河口砂州は右岸砂州と比べ てその幅が広く, 図示する測線 A での浜幅は $230 \mathrm{~m}$ と広 かった。また，左岸河口砂州の突出部分から離岸堤群ま では緩やかに湾曲した汀線が伸びており，とくに西端の 1 号堤の西隣では汀線が離岸堤に滑らかに接していたの に対し，5号堤の東側では汀線が大きく後退し，フック 状となっていた。 このことから2007年当時, 竜洋海岸で は東向きの沿岸漂砂が卓越していたことが分かる.

2008 年では，2007年と比較して測線Aでの浜幅が 155 $\mathrm{m}$ まで減少したが，同時に右岸河口砂州が2007年と比べ て左岸砂州より沖に突出しているのが特徴的であって, 右岸砂州の先端が沖合まで伸びている場合には左岸砂州 の幅が狭いという相関関係が見られる．また，2008年で 


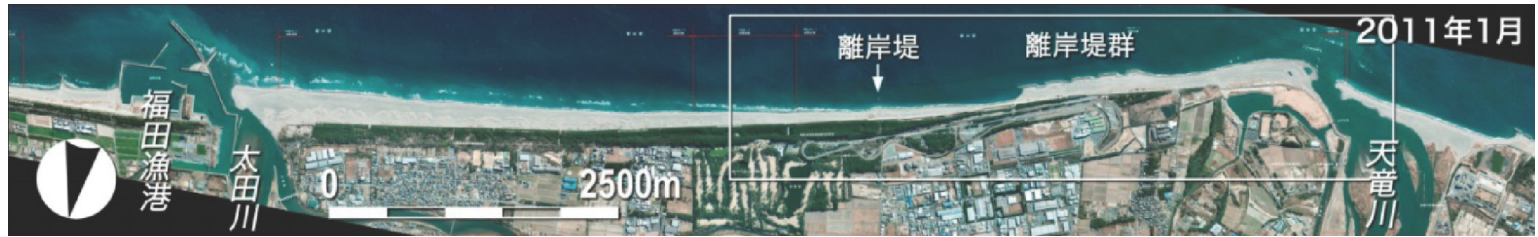

図-1天竜川～福田漁港の空中写真（2011年）

（a）竜洋波浪観測所における有義波高·周期

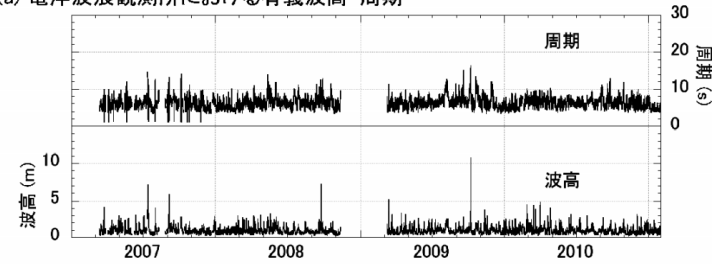

(b) 鹿島観測所 $(25 \mathrm{~km})$ における日流量

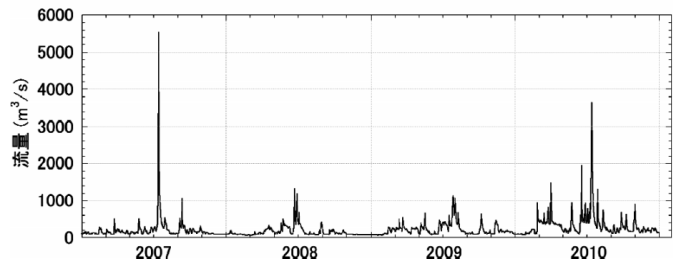

図-2 竜洋海岸沖での波浪観測デー夕と掛塚観測所における 天竜川の流量変化

は河口左岸から離岸堤群へと汀線が直線状に伸びてお り, 離岸堤群の位置では平均汀線は離岸堤と平行に伸び ていた。しかし東端の5号離岸堤の東側で汀線がフック 状に後退する点には変化がない.

2009年になると, A点の東側の砂州の膨らみが消失し て汀線が直線的になった。 また, 右岸砂州が2008年と比 較して後退したと同時に，A点での浜幅が $185 \mathrm{~m}$ まで増加 した。一方，離岸堤周辺では，1号堤西端の汀線がわず かに後退している.さらに, 河口が東側へ移ると同時に, 河口流が斜め東向きに流出している.

2010年では，2009年と比較して右岸砂州が2007年当時 とほぼ同じ位置まで後退したが，これと同期して左岸砂 州はA点付近で大きく膨らみ, 浜幅が $195 \mathrm{~m}$ まで回復した. 2011 年になると, 2010 年と比較して 1 号堤の西側直近の 汀線が後退してフック状となると同時に，天竜川河口で は東側から砂嘴が伸びて河口流の方向が西側へと振れて いる。また，この時期には各離岸堤の開口部の汀線が局 所的に後退してはいるが，5号堤を除いて離岸堤背後は 全面的に砂で満たされている。なお，2010年と2011年の 矢印位置には撤去されたブロックを用いて 6 号離岸堤が 建設され，2011年には長さが $28.8 \mathrm{~m}$ となったため，その 西側の汀線が東側汀線よりわずかに前進している.

2007〜2011年に撮影された垂直写真と同一時刻に撮影 された 5 組の斜め空中写真より, 左岸河口砂州の変化に ついて調べた（図-4）.2007年には幅広い左岸砂州が発 (a) 2007 年
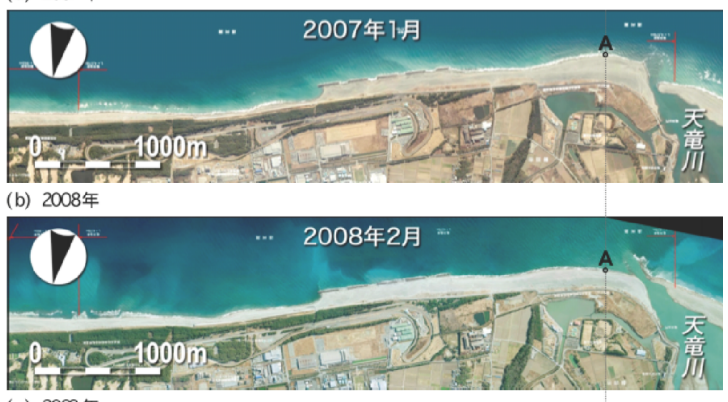

(c) 2009 年

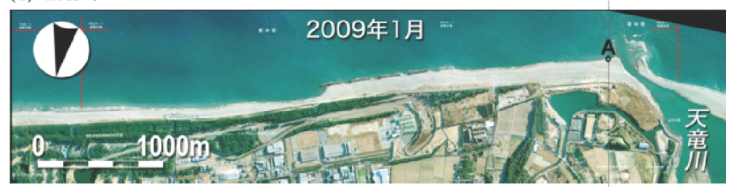

(d) 2010 年

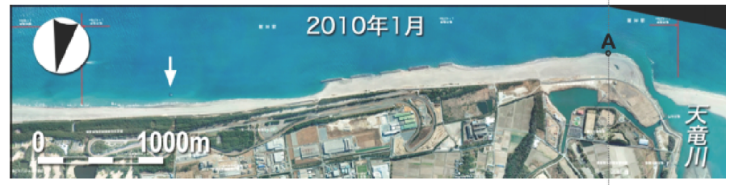
(e) 2011 年

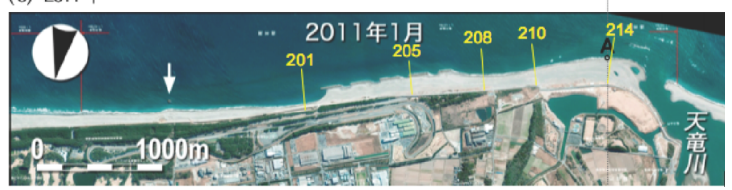

図-3＼cjkstart竜洋海岸の空中写真（2007～2011年)

達していたが，2008年には河口左岸が著しく侵食され， 砂州幅が狭まった。この理由は，2007年7月 15 日に最大 流量 $8,055 \mathrm{~m}^{3} / \mathrm{s}$ の洪水が起き, これによって左岸砂州がフ ラッシュされたためである。一方, 図-4 (b) は洪水後 7 ケ月に撮影されたため，この間河口の汀線に沿って上流 へ遡る沿岸漂砂が生じ, 河道内には矢印aで示す小規模 な砂嘴が伸びた。しかし，2009年には，2008年当時見ら れた小規模な砂嘴は河川流により侵食されて直線的な流 路となり，2008年には侵食により残された砂州の沖合の 平坦面に大量の砂が堆積し, 左岸河口砂州が大きく膨ら んだ. 2010年には, 左岸砂州の発達が続き, 再び2007年 当時の砂州に近い状態まで砂州幅が増した. 2010年から 2011 年までの変化では図-2に示したように2010年 7 月 15 日に洪水が発生したため大きく膨らんだ左岸河口砂州が いったん侵食され, その後河口へと漂砂が逆流して中央 


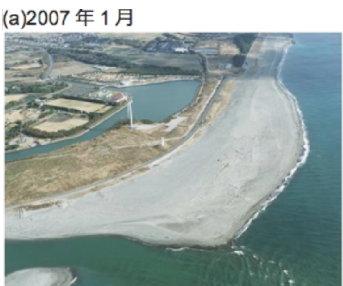

(b) 2008 年 2 月

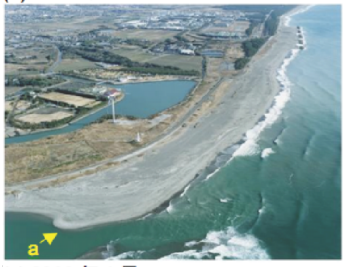

(c) 2009 年 1 月

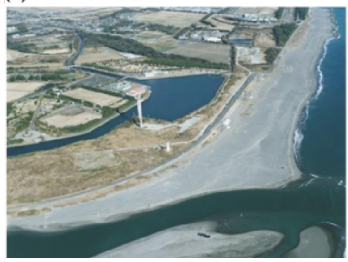

図-4 竜洋海岸の斜め空中写真（垂直写真と同一時刻に撮影）

部にlagoonを囲む砂州が再び発達したことが分かる.

\section{4. 竜洋海岸の汀線と浜幅の変化}

竜洋海岸の長期的変化について調べるために，1962年 基準での 2011 年までの汀線変化を図-5に示す。長期的に 見ると離岸堤群位置では汀線が平均 $25 \mathrm{~m}$ 前進している が，離岸堤群の両側では汀線が後退傾向にある. 離岸堤 群の東側においては，福田漁港近傍の $X=9 \sim 11 \mathrm{~km}$ では 1995 年以降汀線は安定しているが，X=11.2〜 14.8kmでは 汀線後退が著しい. このように離岸堤群の東側では広域 で汀線が後退してきたのに対し，西側でも $X=16.2 \mathrm{~km}$ 付 近を中心とした汀線後退が起きている。図-6は，2008年 基準での2009～2011年の汀線変化を示す．2008年基準 では離岸堤群位置での汀線変化は見られないが，離岸堤 群の両端では2009，2010，2011年の順に汀線が単調に後 退してきたことが分かる。一方，天竜川河口左岸では， 離岸堤西端の汀線変化と逆モードを示して汀線が前進し ている.このように離岸堤〜河口間の汀線変化は，沿岸 漂砂の方向が西向きであることを強く示唆する.しかし， このような西向きの沿岸漂砂が竜洋海岸全体で起きたの であれば，離岸堤群の東側でも同種の汀線変化が起こる べきであるが，実際はそれと逆である， $X=13.6 \mathrm{~km} に$ 設置 された 6 号堤と離岸堤群の間の汀線変化は, 東向きの沿 岸漂砂に起因するものとなっている.

浜幅の分布を図-7に示す。1995年当時，既に離岸堤群 の工事が始められていた，当時，離岸堤群の東側直近の

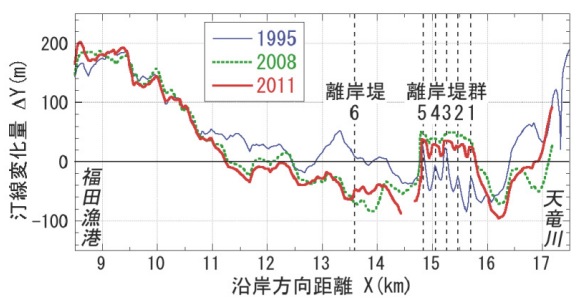

図-5 竜洋海岸の汀線変化（1962年基準）

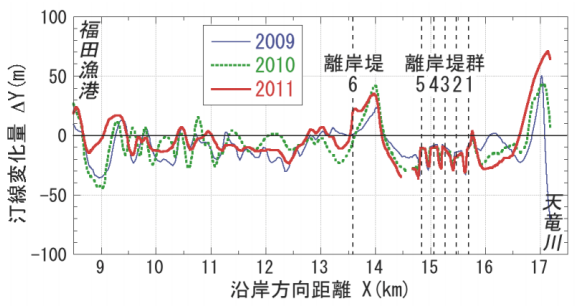

図-6＼cjkstart竜洋海岸の汀線変化（1962年基準）

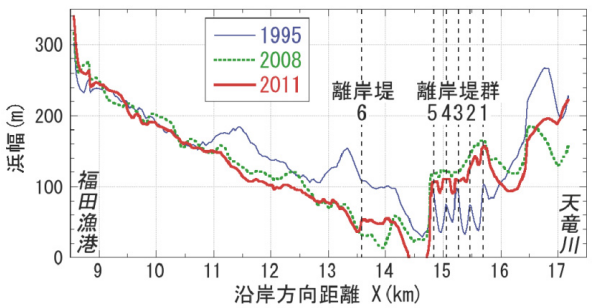

図-7＼cjkstart竜洋海岸の汀線変化（1962年基準）

$X=14.2$ ～14.8kmでは汀線が局所的に大きく後退してはい たが，X=14km 以東ではほぼ $100 \mathrm{~m}$ 以上の浜幅があった。 2008 年までには離岸堤群東端から $X=11 \mathrm{~km}$ 付近までの約 4 $\mathrm{km}$ 区間で汀線が著しく後退し，2011年には $X=14.4 〜$ $14.7 \mathrm{~km}$ では浜幅が 0 となった。浜幅は離岸堤群の東隣で 最も狭く，そこから福田漁港へと東側に距離とともに増 大するという分布を有している。これに対し，離岸堤部 分の汀線は1995年より前進した後, 最近ではほぼ平衡状 態に達している．離岸堤群の東側における汀線変化のみ からは東向きの沿岸漂砂が離岸堤群によって阻止された ため汀線変化が起きたと推定される．東向きの沿岸漂砂 が離岸堤群によって阻止されたのであれば，離岸堤群の 西端では汀線が前進し, 離岸堤の端部を埋めて砂が堆積 しなければならない。しかし実際にはこれと逆に汀線が 後退している。このことは近年天竜川河口から東向きに 連続的に沿岸漂砂が流れる条件ではなくなっていること を意味する。

図-8は，離岸堤群〜天竜川河口左岸の汀線変化を示す. 天竜川河口左岸では，2007年から 2009年にいったん砂州 が後退したが，その後2011年まで左岸砂州が発達し， 2007 年当時の姿とほぼ同一となった. その際，離岸堤群 


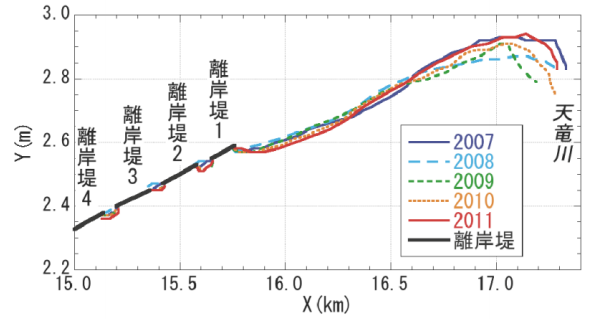

図-8 天竜川河口左岸の汀線変化

の西側では侵食が進み， $X=16.4 \mathrm{~km}$ 付近にある不動点を境 に汀線が反時計回りに回転するような汀線変化が起き た.この原因は, 洪水により左岸砂州が侵食されてから 左岸砂州が再発達する場合, それに必要な砂が東側区域 から運び込まれるためと考えられる. その際, 離岸堤群 が沿岸漂砂の固定境界となって離岸堤群の西側隣接部で は汀線が後退したと推定される.

竜洋海岸は河口デル夕の一部として発達してきたこと, また図-5に示した離岸堤群の東側での汀線変化を考慮す ると, 竜洋海岸では過去に東向きの沿岸漂砂が卓越して きたと考えることが妥当である. しかし近年では竜洋海 岸では河口部の汀線後退とともに強い東向きの沿岸漂砂 は消失し, 漂砂量が $0 に$ 近づいていると考えられ, その ような条件下で, 離岸堤群の西側では天竜川河口砂州の 変動と連動した地形変化が起きていると推定される.

\section{5. 縦断形変化}

対象区域では沿岸方向に $250 \mathrm{~m}$ 間隔に並んだ測線上で 縦断測量が行われてきた。これらの測線のうち，図-3 (e) に示す 5 測線を選んで縦断形比較を行った (図-9参照). No.214では 2008 年に沖合の-5m付近にピークを有するバ ーが発達していたが，2011年までにバー頂部が削られて トラフが埋まり, その付近で新たにバーが発達した。 No.208でも同様な地形変動が見られる. 節点に位置する No.210でも沖合の-5m付近にあったバーが消失している. この間，図-2に示したように2007年には高波浪が作用し たためバーが発達したが，その後比較的静穏な波が続い たためバーの規模の縮小と陸向き移動が起きたと推定さ れる。これらの変動と対照的に, No.214では- $2 \mathrm{~m} 〜+2 \mathrm{~m}$ 間で断面が平行移動しつつ前進しているが, No.210では 縦断形は一定のままで, さらにNo.208ではほぼ-5m以浅 で断面が平行に後退しており，No.214 と逆モードの縦断 形変化が起きている. 断面の前進または後退に合わせて 汀線も前進または後退していることから，先に図-8に示 した汀線変化はこの縦断形変化に対応することが明らか で, 汀線付近の断面形が平行移動するという特徴から, この区間では西向きの沿岸漂砂により地形変化が起きた と推察される。
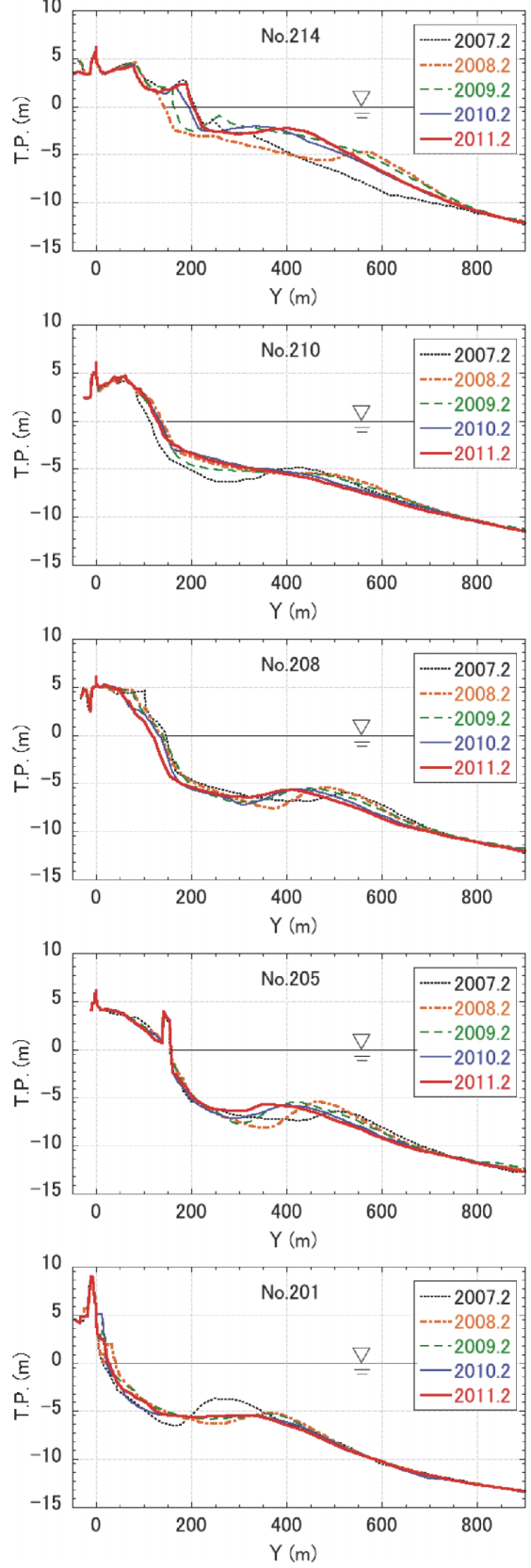

図-9 縦断形変化

次に, 離岸堤群を通るNo.205では, 沖合の-5m以深で 2008 年に形成されていたバーの頂部が削られてそのすぐ 岸側のトラフを埋める変化が起きたが, 離岸堤周辺での 縦断形には変化が見られない。さらに, 離岸堤群の東端 部に位置するNo.201では, 測線では汀線付近が $1 / 8$ と急 勾配で落ち込み急深である。離岸堤群の西側直近の No.208 と, 東側直近のNo.201の縦断形を比較すると, 離 岸堤群の東側のNo.201では-5m以浅の縦断形が凹状であ り，侵食されたあとの縦断形を示すのに対し，No.208で 


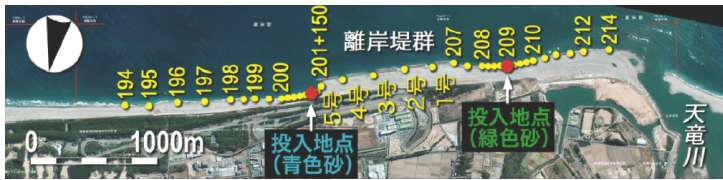

図-10 トレーサー投入地点と汀線に沿うサンプリング地点

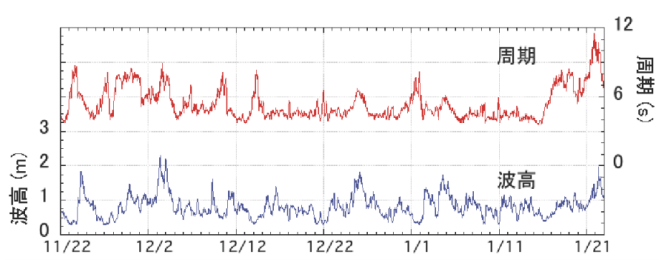

図-11 観測期間中の波浪条件（竜洋波浪観測所）

は-5m以浅が凸状であって堆積後の縦断形となっている. このような縦断形の相違は，離岸堤群の西側では過去に 砂が堆積してきたこと，これに対し離岸堤の東側では侵 食を受けて現況の縦断形となったことを示すと考えられ る。すなわち，離岸堤群の西側区域では，長期的には東 向きの沿岸漂砂の卓越によって縦断形が形成されてきた ものの，近年では縦断形がほぼ安定状態に達し，そのよ うにして形成された海浜地形上で，変動としての西向き の沿岸漂砂の作用が重なったと見られる.

\section{6. カラーサンドによる漂砂観測}

トレーサー調査では，緑色と青色の中砂それぞれ $5 \mathrm{~m}^{3}$ を離岸堤群の西端から 400mのNo.209 と，東端から $100 \mathrm{~m}$ 東のNo. 201 に 2011 年 11 月 22 日に投入し, 投入後 3 日後, $1 ， 2$ 週間後および $1 ， 2$ ヶ月後に図-10に示すように汀線 に沿って $4 \mathrm{~km}$ の区間でサンプリングを行った。サンプリ ングは約 $5 \mathrm{~kg}$ の試料を採取し，1 $\mathrm{mm}$ 以下に篩分けした上 で約 $2 \mathrm{~kg}$ の試料に対しカラーサンドの個数を計測した. 図-11にはトレーサー調査期間中の波浪条件を示す。観 測期間中は $H_{1 / 3}$ が $3 \mathrm{~m}$ 以下で高波浪の襲来はなく, エネル ギー平均波高が $0.9 \mathrm{~m}$ ，周期 $5.4 \mathrm{~s}$ の条件であった。

図-12には離岸堤群西側のNo.209に投入したカラーサ ンドの広がり状況を示す.カラーサンドは離岸堤間でも ごくわずかな個数発見されてはいるが，それらはほとん ど無視できる個数であって, 離岸堤群西側の投入点周り で発見個数が多く，正規分布に近い分布形を有している. また， 2 週間後以降は投入点より西側で発見個数が多い ことから，離岸堤群の西側では拡散しつつ緩やかに天竜 川河口方向へとカラーサンドが移動したことが分かる. これは空中写真や縦断形変化から推定された沿岸漂砂の 方向と一致している。同様に，図-12には，離岸堤群東 側のNo.201+150に投入したカラーサンドの拡散状況を示 す.カラーサンドは投入点より東側で多く発見されてい ることから, 離岸堤群の東側では依然緩やかに東向きの
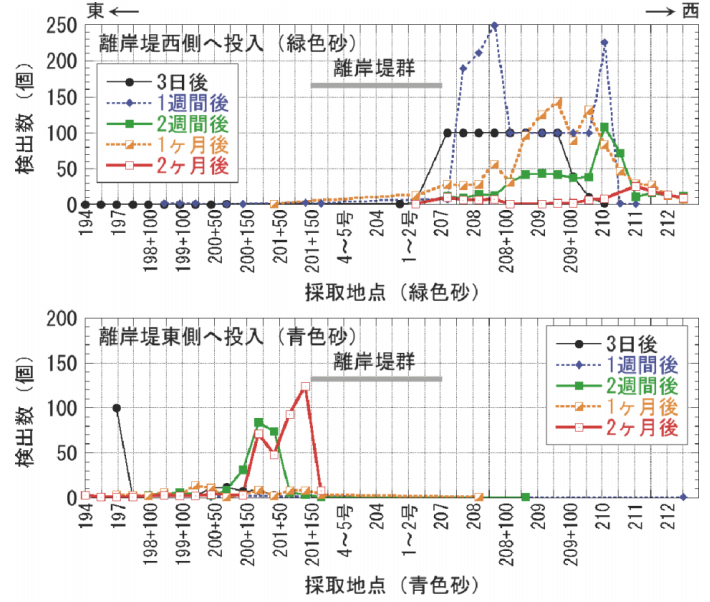

図-12 離岸堤西側と東側に投入したカラーサンドの移動状況

沿岸漂砂が生じている。

\section{7. まとめ}

空中写真や深浅測量データの分析，および新たに実施 したトレーサー調査によれば, 竜洋海岸の離岸堤群から 天竜川河口左岸砂州の間では，洪水によって砂州のフラ ッシュが起こった後, 離岸堤群側から河口方面へと西向 きの沿岸漂砂が起こる条件にある．この沿岸漂砂は，離 岸堤群周辺では図-9に示したように $-5 \mathrm{~m}$ 以浅の約 $1 / 8$ の急 勾配斜面で起きているが，離岸堤群はこの急斜面の中央 に設置されているので，この沿岸漂砂を阻止するものと なっている. しかし $-5 \mathrm{~m}$ 以深の細砂で覆われバートラフ の発達している海底面での砂移動は離岸堤により拘束さ れずに流れることが可能と考えられる. 前浜付近の急勾 配斜面は主として粗砂や碟で構成されているが，この部 分を移動する粗粒分は，従来のように東向きの沿岸漂砂 によって運ばれにくい状態となっている。これより天竜 川からの供給土砂量が激減した条件の下で, 離岸堤群〜 河口間での前浜付近に堆積する粗粒分に関しては海浜地 形がほぼ安定状態に近づいており，この安定状態に変動 が重っていると考えられる。一方，離岸堤群沖では細砂 の移動が可能であるし，また離岸堤群の東側では緩やか な東向きの沿岸漂砂が発達しており，これは汀線変化で 見られた特徴とよく一致する，以上より，竜洋海岸では 離岸堤群があるため粗粒分の移動量はほぼ 0 と見なすこ とができものの, 離岸堤沖については細砂が通過可能と 考えられる.

\section{参 考 文 献}

宇多高明 - 長島郁夫 · 横山卓司 - 松浦吉洋 - 古池 鋼 - 石川 仁憲 (2008) : 静岡県竜洋海岸の海浜変形予測, 海岸工学 論文集，第 55 巻, pp.666-670. 